\title{
Ürün Krizi Döneminde Kurumsal Sosyal Sorumluluğun Etkisi: Tüketicilerin Atfetme Sürecine İlişkin Bir Model Önerisi*
}

\author{
The Effect Of Corporate Social Responsibility During Product-Harm Crisis: \\ Proposing A Model Related To Consumers' Attribution Process
}

Aysun KAHRAMAN ${ }^{1}$

\begin{abstract}
ÖZET
Çevresel faktörlerde yaşanan hızlı dönüşümler, işletmelerin çeşitli krizlerle karşı karşıya kalmasına yol açmaktadır. Krizlerin ortaya çıkmasını engelleyebilmek her zaman mümkün olmamakla birlikte başarılı bir kriz yönetimiyle olumsuz etkiler en aza indirilebilmektedir. İşletmenin kriz öncesi dönemdeki olumlu imajının vurgulandığı aklama kampanyaları kriz yönetiminde sıkça kullanılmaktadır. Bu tür kampanyalarda itibarın boyutlarından birisi olan sosyal sorumluluk faaliyetlerine önemli ölçüde yer verilmektedir. $\mathrm{Bu}$ araştırmada ürün krizi yaşayan bir işletmenin sosyal sorumluluk durumunun, tüketici atfetme süreci bileşenlerini etkileyip etkilemediğini ortaya koymak amaçlanmıştır. Bu doğrultuda, atfetme sürecine dayanan bir model önerisinde bulunulmuş, modelin test edilmesi için senaryolara dayalı nicel bir araştırma tasarlanmış ve 1000 katılımcının yanıtları değerlendirilmiştir. Elde edilen sonuçlar; atfetme sürecinin, modelde önerildiği gibi "atıf-duygudavranış" şeklinde meydana geldiğini ve sosyal sorumluğun atfetme süreci bileșenleri üzerindeki etkisinin işletmenin sosyal sorumlu olup olmamasına göre değiştiğini ortaya koymuştur.
\end{abstract}

Anahtar Kelimeler: Ürün krizi, kurumsal sosyal sorumluluk, atfetme teorisi, atfetme süreci, yapısal eşitlik modellemesi

\section{GíRiş}

İnsanlar yaşamları boyunca çeşitli olaylarla karşılaşmakta, bu süreç içerisinde çevresinde olup bitenleri anlayı kontrol etmeye gereksinim https://orcid.org/0000-0003-4210-3924

\begin{abstract}
The rapid transformations in environmental factors make firms to expose to crisis. Preventing the emergence of the crisis is not always possible, however successful crisis management can be minimize the negative effects. Acquittal campaigns which emphasize the positive image of the firm before crisis may be used frequently during crisis management period. In such campaigns social responsibility activities which is one of the dimensions of reputation is drawn dramatically. The aim of this research is to reveal the effect of being a socially responsible company on the elements of consumers' attribution process. In this regard, a model that addresses the attribution process is proposed and to test this model a quantitative research is designed based on the scenarios, then responses of the 1000 participants are evaluated. The results show that attribution process occurs in the form as "attribution-emotion-behavior" like in the proposed model, the effects of social responsibility on the components of attribution process change based on being socially responsible or not.
\end{abstract}

Keywords: Product-harm crisis, corporate social responsibility, attribution theory, attribution process, structural equation modeling

duymaktadır. Bu gereksinimler kişileri kendilerinin ya da diğer bireylerin davranışlarının, olayların nedenlerini anlamlandırmaya yönlendirmektedir. Bu süreç sosyal psikolojide atfetme olarak adlandırılmaktadır (Kızgın

\footnotetext{
* Bu çalışma, yazarın “Kurumsal Sosyal Sorumluluk Faaliyetlerinin Ürüne illişkin Kriz Dönemlerinde Tüketicilerin Satın Almaya Yönelik Davranışlarına Etkisi: Atfetme Teorisine Yönelik Bir Uygulama" başlıklı doktora tezinin uygulama bölümünün bir kısmından türetilmiştir.

1 Dr. Öğretim Üyesi, Manisa Celal Bayar Üniversitesi Salihli İktisadi ve İdari Bilimler Fakültesi, İşletme Bölümü.
} aysun.kahraman@cbu.edu.tr 
ve Dalgın 2012:61). Atfetme sonucunda yaşanılan olayların nedenleri açıklanarak çeşitli çıkarımlara varılmaktadır. Bu çıkarımlar; tutumların, duyguların, davranışların oluşmasını ve kararların alınmasını etkilemektedir (Vassilikopoulou 2011:281; Goss vd. 2011:381). Nedensel açıklamalar yaşamın her anında yapılmakla birlikte, insanlar özellikle olumsuz bir durumla karşılaştığı anda bunun nedenini daha ciddi bir şekilde sorgulamaktadır (Weiner 2000:383; Donoghue ve Klerk 2006:46). Yaşanan olumsuz durumlardan bazıları tüketici satın alma sürecinde gerçekleşebilmektedir. Satın aldıkları bir üründe sorun çıkmasıyla birlikte tüketiciler, sorunun nedeniyle ilgili çıkarımlar yapmakta, bu çıkarımlar tüketicilerin tepkilerini etkilemektedir (Lei vd. 2012; Ortiz vd. 2017). Yaşanan sorunun ciddiyet derecesinin artarak bir işletme krizi halini alması yapılan çıkarımları daha olumsuz etkilemektedir (Vassilikopoulou vd. 2009:178). Bu nedenle işletmeler krizlerde tüketicilerin olumsuz tepkilerinin derecesini azaltmak için önleyici tedbirler alma yoluna gitmektedir. Bu aşamada yapılacak şeylerden birisi güçlü bir kurumsal itibar oluşturmaktır. Kurumsal itibarın boyutlardan biri kurumsal sosyal sorumluluktur. Sosyal sorumlu bir işletme kriz yaşıyorsa, tüketicilerin işletme hakkında olumsuz düşünme ve işletmeden satın alım yapmayı bırakma olasılığı azalmaktadır (Vassilikopoulou vd. 2009:174). Kurumsal sosyal sorumlulukla ilgili ülkemizdeki pazarlama literatürüne baktığımızda kurumsal sosyal sorumluluk faaliyetlerinin etkilerinin genellikle olağan durumlarda incelendiği görülmektedir. Konu, kurumsal sosyal sorumluluk bileşenleri ve teorileri (Dinçer ve Özdemir 2013; Akdoğan ve Bay 2012; Top ve Öner 2008), tüketicilerin kurumsal sosyal sorumluluk kampanyalarına tutumu (Öksüz 2014; Kaya 2008; Uslu vd. 2008), kurumsal sosyal sorumluluğun marka algısına etkisi (Bayraktar ve Güvenç 2014; Kanıbir vd. 2011; Özdemir 2009), kurumsal sosyal sorumluluğun itibarla ilişkisi (Ural 2012) kurumsal sosyal sorumluluk iletişimi (Sert 2012) çerçevelerinde incelenmiştir. Bununla birlikte olağan olmayan durumlarda bir olguya verilen tepkinin değişip değişmediğini görmek de o durumun etkisini bütünüyle görmek için önemlidir. Kurumsal sosyal sorumluluk açısından konuyu ele aldığımızda olağan ve olumlu durumlarda sosyal sorumluluk faaliyetlerine tüketicilerin olumlu tutumlar sergilediği bilinmektedir (Yönet 2005:252). Böylece aklımıza şöyle sorular gelmektedir: "Işletmeler, sonucu tüketicilere zarar veren olumsuz bir durum yaşadıklarında tüketicilerin kurumsal sosyal sorumluluk faaliyetleri nedeniyle işletmeye beslediği tutumlar olumlu olarak kalmaya devam ediyor mu, bu olumlu tutumlar niyetleri etkiliyor mu?". Buna ek olarak işletmeler, krizlerle karşı karşıya kaldıklarında olumlu imajlarını kaybetmemek için aklama kampanyaları yürütmeye başlamakta ve bu süreçte işletmenin sosyal sorumluluk kampanyalarına da vurgu yapılmaktadır (Özdemir vd. 2017:360). Bu açıdan baktığımızda, işletmeler aklama kampanyalarını kendi faaliyetleri etrafında yürüterek gerçekleştirmektedirler. Ancak bu durum tüketicilerin kendi kendilerine geliştirdikleri süreçleri inmal etmektedir. Oysaki sadece işletmelerin yaptığı faaliyetler değil, tüketicilerin kendi oluşturdukları nedensel açıklama süreci de bu mesajların çözümlendiği alanda önemli olmaktadır.

Kurumsal sosyal sorumluluğun kriz durumlarında işletmeleri nasıl etkilediğini ele alan bu çalışmada yukarıdaki araştırma sorularına cevap aranmaktadır. Çalışma, tüketicilerin kendi kendilerine işletmeyi akladığı bir süreci işaret etmektedir. Araştırmada, ürün krizi yaşayan bir işletmenin sosyal sorumluluk durumunun, tüketici atfetme süreci elamanlarını nasıl etkilediğini ortaya koymak amaçlanmıştır. Çalışma, aklama amacıyla gerçekleştirilen sosyal sorumluluk faaliyetlerinin iletişiminden sonra tüketicilerin çözümleme alanında nasıl bir etki yaratabileceğini ortaya koyarak, literatüre tüketici bakış açısını katmayı amaçlamaktadır.

\section{LITERATÜR ÖZETI}

\section{1. İşletme Krizleri ve İşletmelerde Kriz Yönetimi}

Işsletme bilimi açısından kriz "ne zaman ve ne şekilde ortaya çıkacağı kesin olarak belli olmayan, işletmenin hayatını tehlikeye sokabilecek, hızlı bir şekilde karar almayı ve harekete geçmeyi gerektiren, örgütü derinden etkileyebilecek olaydır" (Örnek 2007:117). Krizler çeşitli açılardan farklı şekillerde sınıflandırılmaktadır. Konuları açısından ele alındığında işletmelerin yaşayabileceği krizlerden birisi ürün krizleridir. Ürün krizi; üretilen ürünün tehlikeli, hatalı, zararlı olarak algılandığı, kamuoyunun ve medyanın gündemine oturan karmaşık olaylar olarak tanımlanmaktadır (Dawar ve Pillutla 2000:215; Siomkos ve Kurzbard 1994:30). Ürünle ilgili olumsuz bir olayın basına yansıması, suçlu tarafın bildirilmesi ve ürünlerin toplatılması durumunda yaşanan sorun artık kriz olarak nitelendirilmektedir (Hsu ve Cheng, 2018:202). Arızalı ürünler, hatalı ürünler, zorunlu güvenlik standartlarına uygun olarak üretilmemiş ürünler, tasarım kusurları, pazarlama stratejilerindeki yanlışlıklar ürün krizleri 
kapsamında ele alınmaktadır (Mullan, 2004). Ürün krizleri sonucunda işletmeler ciddi finansal kayıplara katlanmakta, satışları azalmakta ve kurumsal itibarları zedelenmektedir (Davidson ve Worrell 1992:467; Worden 2011:5-6).

İşletmeler, krizlerle başa çıkabilmek için çeşitli planlar yaparak nasıl davranmaları gerektiğini önceden belirten, gerekli önlemlerin alınmasını kapsayan, krize uyum sağlamayı gösteren bir yaklaşım geliştirmelidirler (Lalonde 2007:510). Bu yaklaşım kriz yönetimiyle sağlanabilmektedir Kriz yönetimi, krizleri algılamak, ortaya çıkmalarına engel olmak, engel olunamadığı takdirde ise zarar verici etkilerini en aza indirmek için gösterilecek her türlü çabayı içermektedir (Pira ve Sohodol 2004:122). Kriz yönetimi çeşitli dönemler halinde yürütülmektedir. Bu süreç "kriz öncesi", "kriz sırası" ve "kriz sonrası" dönemlerin yönetiimi olmak üzere üç ana aşamadan oluşmaktadır. Kriz öncesi dönemin yönetimi proaktif bir yaklaşımı ifade etmektedir. Kriz öncesi dönenim yönetimi sürecinde, krize neden olabilecek olası pürüz ve karmaşıklıkları tespit ederek bunları ortadan kaldırmaya ilişkin olarak planlar yapılmaktadır (Darling 1994:6). Kriz sırası dönemdeki faaliyetler; krizin etkilerini azaltmak ve organizasyonun krizden etkilenmeyen bölümlerine sıçramasını engellemeyi kapsamaktadır (Ofluoğlu ve Mısırlı 2001:3). Kriz sonrası dönemde, krizin değerlendirmesi yapılmakta, krizin açtığı yaralar sarılmakta ve olası krizler için önlemler alınmaktadır (Akdağ ve Arklan 2011:779). Kriz öncesi faaliyetler tedbir niteliğinde olması nedeniyle etkilidir. Kriz öncesi dönemde yapılabileceklerden biri itibar ve imaj çalışmalarıdır. Bu çalışmalar arasında kurumsal sosyal sorumluluk faaliyetleri öne çıkmaktadır.

\subsection{Kriz Yönetiminde Kurumsal Sosyal Sorumluluk Faaliyetleri}

İşletmenin olumlu itibarı tüketicilerin tutumlarını pozitif yönde etkilemektedir. İşletmeye olumlu tutum besleyen tüketiciler işletmeden daha çok satın alım, işletmeye sadakat beslemektedirler (Nakra 2000:36). Ürün/hizmetle ilgili bir sorun ya da kriz öncesinde iyi bir itibara sahip olmak krizin getireceği potansiyel tehlikelerin daha hafifalgılanmasında, olumsuzalgıların silinmesinde son derece etkili olmaktadır (Hess 2008; Nikbin vd. 2011). İtibarı arttırmanın yollarından birisi kurumsal sosyal sorumluluk faaliyetleri yürütmektir. İtibarın boyutlarından birisi olan kurumsal sosyal sorumluluk; işletmenin doğrudan elde edeceği ekonomik ya da teknik faydaların ötesini düşünerek aldığı kararlar ve işletme faaliyetleridir (Davis 1960:70).
Bu, yapılan ilk tanımlardan birisidir. Bununla birlikte kurumsal sosyal sorumluluk için birçok tanım yapılmış, ekonomik sorumlulukların yanında paydaşlar, çevre, toplum gibi sorumluluklar da tanımlara eklenmiştir (Pomering ve Johnson 2009:107; Kotler ve Lee 2006:2-3; Aktan ve Börü 2006:19). Tanımlardaki ortak özelliklerden yola çıkarak kurumsal sosyal sorumluluğu şu şekilde tanımlayabiliriz: "Işletmelerin faaliyetlerinde ve paydaşlarıyla etkileşimlerinde, ekonomik sorumluluklarının yanı sıra toplumla ve doğal çevreyle ilgili unsurları da dikkate alarak gönüllü bir şekilde ahlâklı ve sorumlu davranmasıdır" (Kahraman 2016:56). Potansiyel bir krizden önce yürütülmeye başlanan güçlü, dikkat çekici bir sosyal sorumluluk programı proaktif halkla ilişkiler faaliyetidir ve itibarı korumaya yönelik bir tür sigortadır (Klein ve Dawar, 2004: 204). Işletme, kriz döneminden önce hayırsever ve iyi niyetli davranışlar sergilemişse bunları paydaşlarına hatırlatarak önceden sahip olduğu olumlu imajın etkisini kriz dönemine aktarabilmektedir (Coombs 2007:172; Yoon vd. 2006:377). İşletmenin sosyal sorumlu olması, tüketicilerin krizden sonra ürünü tehlikeli olarak algılama, işletme hakkında olumsuz düşünme ve işletmeden satın alım yapmayı bırakma olasılığını azalmaktadır (Assiouras vd. 2013:116-117; Vassilikopoulou vd. 2009:174).

\subsection{Atfetme ve Atfetme Süreci}

Atfetme; insanların kendilerinin ve diğer kişilerin davranışlarının, yaşadıkları olayların nedenlerini anlama ve açıklama sürecidir (Kızgın ve Dalgın 2012:61). Bu süreçte, karşılaşılan davranışların ve yaşanılan olayların nedenleri açıklanarak çeşitli çıkarımlara varılmaktadır. Atıf (nedensel açıklama) olarak adlandırılan bu çıkarımlar, insanların nedenleri anlaşılmaya çalışılan davranışlara ve olaylara yönelik tutumlarının, beklentilerinin ve davranışlarının oluşmasında etkili olmaktadır (Bemmels 1991:548). Insanların nasıl bir atfetme sürecinden geçtikleri Kelley ve Michela (1980) ve Weiner (1985) tarafından ortaya konmuştur. Kelley ve Michela (1980) bir olay yaşandığında olaydan önceki bilgiler, inançlar ve motivasyonlar doğrultusunda nedensel açıklamalar yapıldığını, bu algılanan nedenlerin davranış, duygu ve beklentileri oluşturduğunu açıklamıştır. Weiner (1985) de çalışmasında atıfların oluşması için öncüllerin varlığına vurgu yapmıştır. Ancak Kelley ve Michela (1980)'dan farklı olarak Weiner (1985)'in modelinde süreç daha belirgin basamaklar halinde işlemektedir. Bu basamaklar bilişsel, duygusal ve eylemsel olmak üzere ardışık olarak sıralanmıştır. Bilişsel basamakta belirli 
bir sonuca bağlı olarak öncül duygular oluşmakta ve bunlar atıfların oluşmasına neden olmaktadır. Yapılan atıflar daha sonra nedene bağlı belirli duyguların oluşmasını sağlamaktadır. Bu, duygusal basamaktır. Duygulara bağlı olarak kişiler eylemsel tepkilerde bulunmaktadır. Bu da eylemsel basamaktır (Weiner 1985:560-568). Nedensel açıklamalar yaşamın her anında yapılmakla birlikte, insanlar özellikle olumsuz olaylarla karşılaştıklarında ortamdaki belirsizlik ve tedirginlik nedeniyle bunun nedenini bilmeye daha çok ihtiyaç duymakta ve daha dikkatli bir şekilde yargılama yapmaktadırlar (Donoghue ve Klerk, 2006:46; Weiner 2000:383). Bu olumsuz durumların bir kısmı tüketicilerin satın alma süreçleriyle ilgili olarakmeydana gelebilmektedir. Olumsuz durumlarda tüketicilerin atfetme sürecine yönelik birçok araştırmada Weiner'in (1980)'in Başarıya Bağlı Atfetme Teorisi temel alınmıştır (Lei vd., 2012; Nikbin vd., 2011; Hess, 2008; Poon vd. 2004; Klein ve Dawar, 2004; Casado-Diaz ve Más-Ruíz, 2002; Sen ve Bhattacharya, 2001; Folkes vd., 1987; Folkes, 1984). Weiner (1980)'in Teorisi'nin temel odağı, bireyin başarısının sebeplerini nasıl algıladığı ve bu algıların geçerli davranışüzerindeki doğrudan ve dolaylı etkileridir. Bu sebepler teoride nedensel boyutlar olarak açıklanmıştır ve atfetme sürecinde bilişsel basamağı oluşturmaktadır. Nedensel boyutlar, davranışların sebeplerinin açıklanmasına yol göstermektedir. Teoride odak noktası, kalıcılık ve kontrol edilebilirlik şeklinde üç boyut vardır. 1.Odak noktası, atıfın içsel ya da dışsal olarak yapılmasıyla ilgilidir. İçsel atıf, kişinin kendisini ve özelliklerini, durumunun nedeni olarak görmesidir. Dışsal atıf ise davranışın ve durumun nedeninin kişinin dışındaki faktörler olduğunu düşünmesidir. (Weiner 1985:551). Bireyin kişilik özellikleri, tutumları, çabaları, ruh hali ve çabaları içsel; başka bireylerin davranışları, şans ve o kişinin içinde bulunduğu koşullar dışsal atıflara örnektir (Kağıtçıbaşı ve Cemalcılar, 2014:111). 2.Kalıcılık olayın nedenlerinin uzun süreli, devam eden türden olup olmamasıyla ilgilidir. Eğer bir olay kalıcı bir nedene bağlanırsa aynı ya da benzer bir olayın gelecekte tekrar yaşanma ihtimaline yönelik kesinlik artmaktadır (Weiner 1985:559). 3.Kontrol edilebilirlik, kişinin başarılı ya da başarısız olarak değerlendirdiği şeylerin kendisi tarafından ne kadar kontrol edilebilir olduğu ile ilgilidir. Örneğin bir olayın nedeni şanstan kaynaklanabilir ve insanların şans faktörü üzerinde kontrol gücü yoktur (Weiner 1983:531). Boyutlar birbirini de etkilemektedir. Bazı nedenler içsel ve kalıcı ya da dışsal ve kalıcı olabildiği gibi içsel ve geçici ya da dışsal ve geçici de olabilmektedir (Weiner 2000:385).
Ürün krizlerinin yaşandığı dönemlerde de tüketiciler bir atfetme sürecinden geçmektedir. Olumsuz tüketim tecrübesi sonunda tüketiciler ilk olarak olayın nedeni ve sorumlusuna ilişkin atıflar (çıkarımlar) yapmaktadır (Klein ve Dawar, 2004:204; Lei vd., 2012:338). Atıflar müşteri tepkilerinin yönünü ve derecesini de belirlemektedir. Atfetme modellerindeki gibi ürün/ hizmetlerle ilgli sorun yaşandığında atıflar ilk olarak tüketici duygularını etkilemektedir (Vassilikopoulou, 2011:281). Yapılan araştırmalarda, satın alınan ürün/ hizmette sorun çıkması durumunda tüketicilerin kızgınlık, belirsizlik, hayal kırıkığı, pişmanlık, şaşkınlık, tiksinti, utanç, rahatsızlık, tedirginlik, memnuniyetsizlik hissettikleri tespit edilmiştir (Folkes, 1984:399; Smith ve Bolton, 2002:12; Wetzer vd., 2007:667). Yaşanan duygular atıflara göre değişmektedir. Sorunun nedeninin işletme kökenli, kalıcı ve kontrol edilebilir olduğu düşünülüyorsa duyguların olumsuzluğu artmaktadır (Vlachos vd., 2009; Lei vd., 2012). Atıflar ve duygular tüketicilerin davranışlarını etkilemektedir. Işletme sorundan sorumlu tutuluyorsa, tüketiciler işletme hakkında çevresine olumsuz beyanlarda bulunmakta, işletmeyi şikâyet etmekte, işletmeden tekrar satın almayı bırakmakta, yaşanan olumsuzluğu işletme tarafından telafi edilmesini talep etmektedir (Coombs ve Holladay, 2002:168; Goss vd., 2011:381). Sorunun işletmenin kontrolünde olduğuna inanan tüketicinin işletmeye duyduğu güvenle birlikte tekrar satın alma niyeti de azalmaktadır (Vlachos vd., 2009). Kızgınlık duygusu da tekrar satın almadan kaçınmaya neden olmaktadır (Ortiz vd. 2017:450). Atfetme süreci modellerinden ve önceki araştırma bulgularından yola çıkılarak aşağıdaki hipotezler oluşturulmuştur:

$\mathrm{H}_{1}$ : Atıfların müşterilerin olumsuz duyguları üzerinde pozitif yönde etkisi vardır.

$\mathrm{H}_{1 \mathrm{a}}$ : Kontrol edilebilirlik boyutunun müşterilerin duyguları üzerinde etkisi vardır.

$\mathrm{H}_{16}$ : Kalıcılık boyutunun müşterilerin duyguları üzerinde etkisi vardır.

$\mathrm{H}_{1 \mathrm{c}}$ : Odak noktası boyutunun müşterilerin duyguları üzerinde etkisi vardır.

$\mathrm{H}_{2}$ : Müşterilerin olumsuz duygularının tekrar satın alma niyetleri üzerinde negatif yönde etkisi vardır.

\subsubsection{Kurumsal Sosyal Sorumluluk Faaliyetlerinin Olumsuz Tüketici Deneyimlerinde Atfetme Sürecine Etkisi}

Olumsuz tüketici tecrübeleri sonunda yapılan atıflar doğrultusunda tüketicilerin ilk olarak suçlama 
davranışında bulunacaklarından bahsedilmektedir. Ürün ya da hizmetle ilgili bir sorun yaşandıklarında genellikle tüketiciler işletmeyi sorumlu tutma ve suçlama, işletmeler ise tüketiciyi sorumlu tutma fakat suçlamama eğilimde olmaktadırlar (Folkes ve Kotsos 1986:74). Farklı atıflar farklı inançların, beklentilerin ve davranışların oluşmasına neden olmaktadır. İşletmeyi suçlama eğiliminde olan tüketici ciddi bir telafi beklerken, satıc sorunun kendinden kaynaklanmadığını düşünerek telafi davranışına yanaşmayabilmektedir (Folkes 1984:407). Olumsuz tüketici tecrübeleri dönemlerinde işletmenin itibarı ve sorun karşısında suçlanacak taraf arasında da bir ilişki vardır. Ürünle ilgili bir kriz yaşandığında işletmenin itibarı yüksekse tüketiciler sorun karşısında daha çok ürün kullanıcılarını suçlarken işletmenin itibarı yüksek değilse kurumu suçlamaya eğilimli olmaktadırlar (Laczniak vd. 2006:66). Nikbin vd. (2011) de hizmet sunumunda başarısızlık yaşandığında itibarla tekrar satın alma davranışı arasındaki olumlu ilişkinin sorunun kontrol edilebilir veya kalıcı olarak algılanması durumunda zayıflayacağını tepsit etmiştir. İtibarın boyutlarından olan kurumsal sosyal sorumluluğun da tüketici atıfları ve suçlama eğilimleri üzerinde etkisi vardır. İşletmenin sosyal sorumluluk faaliyetlerine olumlu tutumlar besleyen tüketicilerin kriz yaşandığında sorunun kaynağını işletme olarak görme ve sorunun sürekli olacağına inanma eğilimleri azalmaktadır (Klein ve Dawar 2004:207). Ayrıca sosyal sorumlu olmak bir kriz döneminde, işletmeye yönelik olarak yapılacak değerlendirmelerin olumsuzluk derecesini azaltırken, tekrar satın alma niyetini olumlu yönde etkilemektedir (Assiouras vd., 2013:116; Klein ve Dawar 2004:207). Bu bulgulara göre aşağıdaki diğer hipotezler öne sürülmüştür:

$\mathrm{H}_{3}$ : Işletmenin sosyal sorumluluk durumunun müşterilerin atıfları üzerinde etkisi negatif yönde vardır.

$\mathrm{H}_{3 \mathrm{a}}$ : Işletmenin sosyal sorumluluk durumunun kontrol edilebilirlik boyutu üzerinde etkisi vardır.

$\mathrm{H}_{3 \mathrm{~b}}$ : Işletmenin sosyal sorumluluk durumunun kalıcılık boyutu üzerinde etkisi vardır.

$\mathrm{H}_{3 c}$ : işletmenin sosyal sorumluluk durumunun odak noktası boyutu üzerinde etkisi vardır.

$\mathrm{H}_{4}$ : İsletmenin sosyal sorumluluk durumunun müşterilerin olumsuz duyguları üzerinde negatif yönde etkisi vardır.

$\mathrm{H}_{5}$ : İşletmenin sosyal sorumluluk durumunun müşterilerin tekrar satın alma niyetleri üzerinde pozitif yönde etkisi vardır.

\section{KURUMSAL SOSYAL SORUMLULUK FAALIYETLERININ ÜRÜN KRIZi DÖNEMINDE TÜKETICI ATFETME SÜRECINE ETKISI ÜZERINE BIR ARAŞTIRMA}

\subsection{Araştırmanın Amacı ve Yöntemi}

$\mathrm{Bu}$ araştırmanın amacı ürün krizi yaşayan bir işletmenin sosyal sorumluluk durumunun, tüketici atfetme süreci bileşenlerini etkileyip etkilemediğini ortaya koymaktır. Bu doğrultuda, atfetme sürecini ele alan bir model önerisinde bulunulmuş, modelin test edilmesi için senaryolara dayalı nicel bir araştırma tasarlanmıştır. Araştırmada anket tekniği kullanılmıştır. Anket soruları benzer konulu çalışmalarda daha önce kullanılan ve güvenilirlikleri yüksek ölçeklerden yararlanılarak oluşturulmuştur. Kurumsal sosyal sorumlulukla ilgili tüketici algısı için (6 madde) Bigne-Alcaniz vd., 2009; Brown ve Dacin, 1997; Menon ve Kahn, 2003; duygular için (6 madde) Smith ve Bolton, 2002; Wang ve Huff, 2007; atfetme için (14 madde) Klein ve Dawar, 2004; Nikbin vd., 2011; Poon vd., 2004; tekrar satın alma niyeti için (6 madde) Zeithaml vd., 1996; Vassilikopoulou vd., 2011 tarafından geliştirilen ölçekler kullanılmıştır. Odak noktası boyutu için orjinal ölçek, sorularda bütünlüğün sağlanması için derecelemeli ölçekten likert tipi ölçeğe dönüştürülmüştür. Katılımcılara 5 'li likert tipi ölçek üzerinde verilen ifadelere katılma dereceleri sorulmuştur. Ölçekler oluşturulduktan sonra ölçeklerin Türkçe çevirisi iki farklı akademisyen tarafından yapılmış, daha sonra Türkçe çeviri ilk çeviriyi yapanlardan farklı iki akademisyen tarafından tekrar Ingilizceye çevrilmiştir. Anket soruları hazırlanırken ayrıca nitel bir araştırmadan da destek alınmıştır. $\mathrm{Bu}$ aşamada 30 kişiyle derinlemesine görüşmeler yapılarak ürün/hizmetle ilgili yaşanılan bir sorunun ne tür tüketici tepkilerine yol açtığı, işletmenin sosyal sorumlu olması durumunda tüketicilerin tepkilerinin değişip değişmediği ortaya konulmaya çalışılmıştır. Araştırmada kurumsal sosyal sorumluluğun etkisi manipülasyon yapılarak ölçülmüştür. Manipülasyon senaryolar yazılarak yapılmış ve iki farklı anket formu hazırlanmıştır. Birinci anket formunda sosyal sorumlu bir işletme, ikinci anket formunda sosyal sorumlu olmayan bir işletme üzerinden senaryo yazılmıştır. Senaryolar yazılırken kurumsal sosyal sorumluluğun boyutları geçmiş araştırmalar da incelenerek dikkate alınmıştır. Senaryoların kullanılması gerçek bir durumla ilgili hatırlama hatalarından ve rasyonelleştirme eğilimlerinden kaynaklanan yanlılıkları azaltmaktadır (Brown ve Dacin, 1997, Lei vd., 2012). Model ürün 
krizi durumunda test edileceği için araştırmada her iki ankette de aynı olacak şekilde ürün kriziyle ilgili bir senaryo daha yazılmıştır. Ürün krizinin senaryosu yazııırken araştırma kapsamında yapılan derinlemesine görüşme sonuçlarından, ürün krizi konu edilmiş geçmiş araştırmalardaki senaryolardan ve sikayetvar. com sitesindeki gerçek tüketici şikâyetlerinden yararlanılmıştır. Böylece senaryodaki işletmenin teknoloji alanında faaliyet göstermesine, ürünün cep telefonu olmasına ve olayın şarj sonrasında telefonda belirli bir süreliğine önemli bir yavaşlama olması şeklinde karar verilmiştir. Olay bir ürün krizini anlattığı için sorunun haberlere konu olduğuna, sorumlu tarafın kim olabileceğine ilişkin uzman görüşlerinin tartışıldığına yönelik bilgilere de senaryoda yer verilmiştir. Yazılan senaryolarda olaylar Tech-Rex adlı hayali bir cep telefonu üreticisi üzerinden anlatılmıştır. Anket sorularının, senaryoların uygunluğu alan uzmanlarınca değerlendirilmiştir. Hayali bir işletme kullanmak, denek yanlıığını en aza indirmektedir (Siomkos 1999: 21). Gerçek bir işletmenin kullanılması durumunda işletme ile ilgili mevcut tutumlar, tüketicilerin vereceği tepkileri yanlı kılabilmekte ve katılımcıların kafalarını karıştırabilmektedir (Klein ve Dawar 2004:206). Hazırlanan anketler ilk aşamada 60 kişiye yüz yüze uygulanarak pilot test yapılmıştır. Pilot test sonrasında ifadeler üzerinde birtakım düzenlemeler yapılmıştır. Atfetme boyutlarında ifadelerin anlamlarını bozmadan cümlelerin biraz daha açıklayıcı hale getirilmiştir. Ayrıca, kurumsal sosyal sorumlulukla ilgili tüketici algısı ölçeğine 2 madde, kontrol edilebilirlik ölçeğine 1 madde eklendikten sonra tekrar uzman görüşü alınmıştır. Bunların dışında değişiklikler yapılmamıştır. 17.03.2016 - 27.04.2016 tarihleri arasında asıl araştırma gerçekleştirilmiştir. Araştırmanın ana kütlesini İzmir veya Manisa ilinde ikamet eden 18 yaş üstü tüketiciler oluşturmaktadır. Elden dağıtılan anketler için kolayda örnekleme, internet ortamında yapılan anketler için internet örneklemesi yöntemleriyle veriler yoplanmıştır. 2016 yılı ikamet edilen ile göre nüfus kayıtlarına göre İzmir'in nüfusu 1.707.347, Manisa'nın nüfusu 1.009.349'dur. Evren hacminin 1.000 .000 olması durumunda 384 örneklem büyüklüğü yeterli olmaktadır (Yazıcıoğlu ve Erdoğan 2007:72). Sosyal sorumlu işletmenin anlatıldığı anket için toplam 606 katılımcıya, sosyal sorumlu olmayan işletmenin anlatıldığı anket için toplam 585 katılımcıya ulaşıımıştır. Bir sayfanın ya da bir ölçeğin tamamıyla boş bırakıldığı, İzmir/Manisa illerinde ikamet etmeyen ve 18 yaşın altındaki katılımcıların cevapladığı anketler değerlendirmemiştir. Kalan anketler SPSS 23.0 programıyla kaydedilmiştir. Örneklem büyüklüğünün yeterlilik düzeydeki bozulmadan şüpheli bulunan uç değerler de analizden çıkarılmıştır. Uç değerler, diğer verilerle karşılaştırıldığında veri setine uygun olmadığı düşünülen aşırı değerlerdir. Uç değer analizinin yapısal eşitlik modellemesinin yöntemi uygulamaya geçmeden önce yapılması gerekmektedir (Çokluk vd., 2012:274). Buna göre sosyal sorumlu işletmenin anlatıldığı anket için 500, kurumsal sosyal sorumlu olmayan işletmenin anlatıldığı anket için 500 katılımcıyla veri tabanı son halini almış, analiz aşamasına geçilmiştir.

\subsection{Araştırma Modeli}

Rutin olmayan durumlarda kişilerin oldukça yaygın bir şekilde sergilediği bilişsel süreç atfetmedir (Folkes 1984). Bu açıdan bu çalışma için atfetme teorisi çerçevesinde tasarlanmış bir araştırmanın uygun olacağı düşünülmüştür. Araştırmada Weiner'in (1985) atfetme süreci modeline dayandırılarak bir araştırma modeli oluşturulmuştur. Weiner'in teorisi bireylerin başarısızlık durumuyla karşılaştığında yapacağı atıfların özellikleriyle ilgilidir. Ürün/hizmetlerle ilgili sorun yaşanması durumunda tüketiciler, başarısızlık durumuyla karşı karşıya kalacağı için Weiner'in (1985) teorisinin bu araştırmaya uygun olduğu düşünülmüştür. Daha önce de bahsedildiği gibi ürün krizi ve tüketici atıfları konusunu inceleyen birçok çalışmada da Weiner (1985)'in atfetme teorisi temel alınmıştır. Modelde Weiner (1985)'in modeline sosyal sorumluluk değişkeni eklenmiş, davranış değişkeni için tekrar satın alma niyeti kullanılmıştır. Ayrıca orijinal modelden farklı olarak atıf değişkeninin davranışa doğrudan etki edeceği düşünülerek bu durum modele eklenmiştir. 


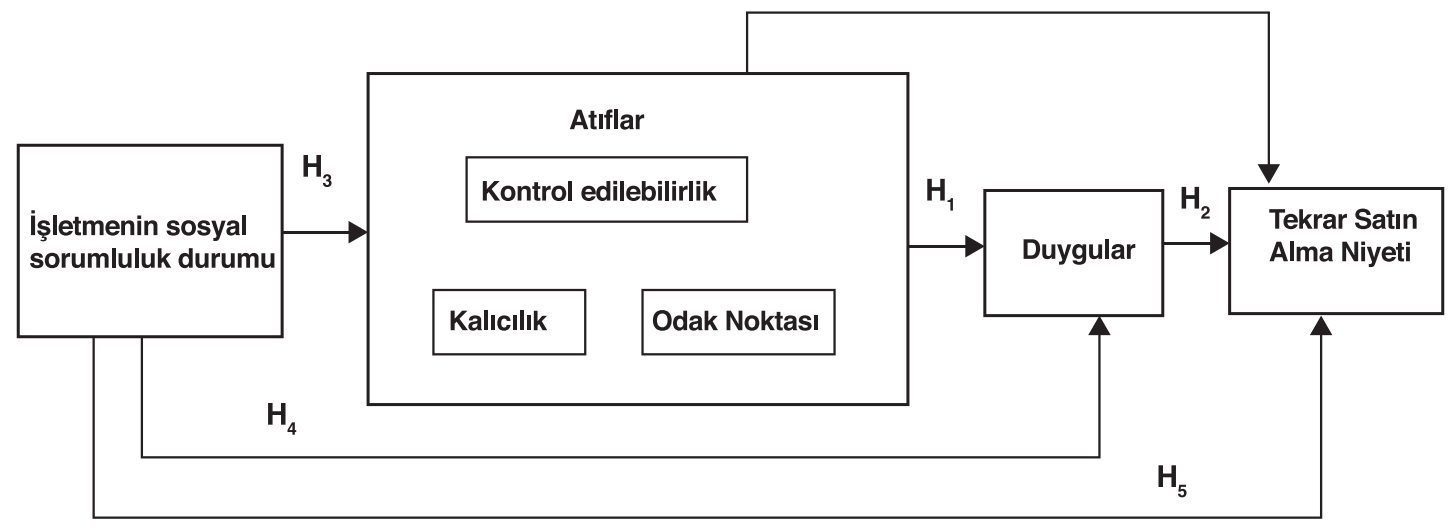

Şekil 1: Önerilen Araştırma Modeli

\section{Araştırma Bulguları}

\subsection{Demografik Özellikler}

Katılımcıların demografik özellikleri hipotezlerde yer almasa da bize araştırmaya katılanların genel profilini vermektedir. Demografik bulgulara göre her iki grubun da özellikleri birbirine benzemektedir. Katılımcıların yarıdan biraz fazlası kadın, çoğunluğu 24-26 yaş aralığında, lise mezunu ve $3.501-4.000$ TL arası gelire sahiptir.

\subsection{Manipülasyon Kontrolü}

Araştırma kurgusundaki manipülasyonun başarılı olması için kullanılan senaryoların istenen etkiyi yaratıp yaratmayacağına dair bir ön test pilot çalışma sırasında yapılmıştır. Sosyal sorumluluk ölçeğindeki sorulara verilen cevapların ortalaması alınarak katıımcıların senaryodaki işletmeyi ne ölçüde sosyal sorumlu olarak değerlendirdiğine bakılmıştır. İşletme sosyal sorumlu olduğu durumda katıımcılar işletmenin sosyal sorumlu olduğuna " 3,86 " ortalamayla, sosyal sorumlu olmadığı durumda ise "2,07" ortalamyla katılmaktadır. Aynı süreç asıl araştırma için de yapılmış, sosyal sorumlu işletme için ortalama " 4,19 ", sosyal sorumlu olmayan işletme için "1,41" bulunmuştur. Böylece senaryolardaki kurguların doğruluğunu onaylanmıştır.

\subsection{Güvenilirlik ve Doğrulayıcı Faktör Analizleri}

Veriler toplandıktan sonra temel analizlere geçmeden önce güvenilirlik testleri yapılmış ve aşağıdaki değerler elde edilmiştir:

Tablo 1: Ölçeklerin Güvenilirlik Analizleri

\begin{tabular}{|c|c|c|c|c|c|c|}
\hline \multirow[t]{2}{*}{ Ölçeğin Adı } & \multicolumn{2}{|c|}{ Cronbach's a } & \multicolumn{2}{|l|}{ Ortalama } & \multicolumn{2}{|l|}{ Varyans } \\
\hline & SS İşletme & $\begin{array}{l}\text { SS Olmayan } \\
\text { İşletme }\end{array}$ & SS İşletme & $\begin{array}{l}\text { SS Olmayan } \\
\text { İşletme }\end{array}$ & SS İşletme & $\begin{array}{l}\text { SS Olmayan } \\
\text { İşletme }\end{array}$ \\
\hline Sosyal sorumluluk (8) & 0,853 & 0,848 & 0,427 & 0,412 & 0,007 & 0,009 \\
\hline Duygular (6) & 0,871 & 0,834 & 0,523 & 0,467 & 0,024 & 0,022 \\
\hline Atıf-Kontrol (4) & 0,867 & 0,857 & 0,643 & 0,600 & 0,006 & 0,006 \\
\hline Atıf-Kalıcılık (4) & 0,737 & 0,713 & 0,407 & 0,382 & 0,048 & 0,029 \\
\hline Atıf-Odak noktası (6) & 0,426 & 0,427 & 0,111 & 0,121 & 0,020 & 0,020 \\
\hline Satın alma niyeti (6) & 0,911 & 0,834 & 0,629 & 0,484 & 0,024 & 0,043 \\
\hline
\end{tabular}


Elde edilen sonuçlara göre atıf-odak noktası boyutu dışındaki ölçeklerin güvenilirlik derecesi yüksektir. Odak noktası boyutu için bazı maddeler çıkartılarak güvenirlik testleri tekrarlanmıştır. Yine de güvenilirlik düzeyinin beklenen değer olan 0,70 'ten oldukça düşük çıkmıştır. Ölçeğin içsel tutarlılığı modeli olumsuz etkileyeceği için odak noktası boyutu modelden çıkartılmıştır. Orijinal ölçekteki dereceleme yerine likert tipi bir ölçeğe geçiş güvenirliği düşürmüş olabilir. Odak noktası atfetmenin boyutlarından birisi olmakla beraber bir sorun yaşandığı zaman müşterilerin büyük ölçüde işletmeyi sorumlu tutma eğiliminde olmaları nedeniyle bazı araştırmalarda bu boyut baştan model dışında tutulmuştur (Folkes vd. 1987; Bitner 1990; Smith vd. 1999; Hess vd. 2003; Nikbin vd. 2011).

Ölçeklerin geçerliliğini ölçmek için LISREL 8.51 programı kullanılarak doğrulayıcı faktör analizleri yapılmıştır. Illk olarak sosyal sorumlu olduğu işletme için analiz yapılmış, modelinin $\mathrm{t}$ değerlerindeki tüm faktör yüklerinin 0,05 anlamlılık düzeyinde 1,96 değerinden büyük ve istatistiksel olarak anlamlı olduğu görülmüştür. Standartlaştırılmış değerlerde kalıcılık değişkenine ait "Bu soruna ait nedenlerin zaman içinde ortadan kalkacağına inanıyorum" maddesinin hata varyansı yüksek $(0,93)$, faktör yükünün düşüktür $(0,26)$. Diğer değişken değerleri istenilen düzeydedir. Daha sonra uyum indekslerine bakılmıştır. Model uyumu testi için sık kullanılan değerler olan $x^{2} / \mathrm{df}, \mathrm{CFI}, \mathrm{RMSEA}$, GFI, AGFI ölçüt olarak alınmıştır (Şimşek, 2007:14). Uyum indekslerine baktığımızda $\times 2 / \mathrm{sd}=2,66 ; \mathrm{CFI}=0,93$; RMSEA $=0,058 ; \mathrm{GFI}=0,89 ; \mathrm{AGFI}=0,86$ şeklindedir. Uyum değerleri genel olarak kabul edilebilir ölçütlerdedir. İşletmenin sosyal sorumlu olmadığı durum için ölçme modelinin $\mathrm{t}$ değerlerine bakıldığında tüm faktör yükleri 0,05 anlamlılık düzeyinde 1,96 değerinden büyük, istatistiksel olarak anlamlıdır. Standartlaştırılmış değerlerde kalıcılık değişkenine ait "Bu soruna ait nedenlerin zaman içinde ortadan kalkacağına inanıyorum" maddesinin hata varyansının yüksek $(0,90)$, faktör yükünün düşük $(0,31)$; tekrar satın alma değişkenine ait "Tech-Rex'in ürünlerinden gelecekte daha az satın alırım" maddesinin de hata varyansının $(0,92)$ yüksek, faktör yükünün düşük $(0,28)$ olduğu ortaya çıkmıştır. Diğer değişkenlerin değerleri istenilen düzeydedir. Uyum indeksleri $\mathrm{X}^{2} /$ $\mathrm{sd}=2,04 ; \mathrm{CFI}=0,95 ; \mathrm{RMSEA}=0,046 ; \mathrm{GFI}=0,91 ; \mathrm{AGFI}=0,89$ şeklindedir. Yapısal eşitlik modellerinde hata varyansının yüksek, faktör yükünün düşük olmaması istenmektedir. Bu nedenle hata varyansı yüksek, faktör yükü düşük olan maddeler çıkartılarak tekrar doğrulayıcı faktör analizleri yapılmıştır. İkinci analiz sonrasında uyum indekslerinde iyileşme görülmüştür. Yeni modeldeki uyum değerleri sosyal sorumlu işletme için $x^{2} / s d=2,61 ; \quad C F I=0,94 ; \quad R M S E A=0,057$; $\mathrm{GFI}=0,90 ; \mathrm{AGFI}=0,87$ sosyal sorumlu olmayan işletme için $X^{2} / s d=2,04 ; C F I=0,95 ; \operatorname{RMSEA}=0,046 ; G F I=0,92$; $A G F I=0,90$ 'dır. Maddeler çıkartılarak yapılan doğrulayıcı faktör analizi sonrasında elde edilen değerlerin daha iyi olduğu görülmektedir. Bu sonuç yeni faktör modelinin veriye daha iyi uyum sağladığının göstergesidir. Araştırmaya bu şekilde devam edileceği için güvenilirlik katsayıları yeniden hesaplanmıştır. Sosyal sorumlu işletme durumunda Cronbach's Alpha değeri kalıcilık değişkeni için 0,826'ya, tekrar satın alma değişkeni için 0,929'a çıkmıştır. Sosyal sorumlu olmayan işletmede Cronbach's Alpha değeri kalıcılık değişkeni için 0,879'a, tekrar satın alma değişkeni için 0,891'e yükselmiştir.

\subsection{Gizil Değişkenlerle Yol Analizi}

Doğrulayıcı faktör analizinden sonra yapısal modelin testi için sosyal sorumlu ve sosyal sorumlu olmama durumlarının her ikisi için de gizil değişkenlerle yol analizleri yapılmıştır.

\subsubsection{Sosyal Sorumlu İşletme İçin Yol Analizi}

Yol analizi yapılırken öncelikle modelin uygunluğu için gerekli ölçütler incelenmiştir. Uyum indeksleri $X^{2}$ / $\mathrm{sd}=2,97 ; \mathrm{CFI}=0,92 ; \mathrm{RMSEA}=0,063 ; \mathrm{GFI}=0,88 ; \mathrm{AGFI}=0,86$ şeklinde ortaya çıkmıştır. Sonuçlara göre, model verilere iyi uyum sağlamaktadır.

Şekil 2.'deki t değerlerine göre Sosyal sorumluluk düzeyi (Kss) ile Atıf-kontrol edilebilirlik boyutu (Kontrol), Atıf-kalıcılık boyutu (Kalici), Duygular (Duygu) değişkenleri arasındaki ilişkiyi gösteren değerler kritik değer olan 1,96 değerinden küçük olduğu için 0,05 anlamlılık düzeyinde anlamsızdır. Böylece $\mathrm{H}_{3 \mathrm{a}^{\prime}}$ $\mathrm{H}_{3 b^{\prime}}, \mathrm{H}_{3 c}$ reddedilmiştir. Bunların dışındaki t değerleri 1,96 değerinden büyük, 0,05 anlamlılık düzeyinde istatistiksel olarak anlamlıdır. Reddedilen hipotezlere göre işletmenin sosyal sorumlu olup olmaması yapılan atıfları ve negatif duyguları etkilememektedir. Bu bulgu, Klein ve Dawar (2004) tarafından daha önce yapılan bir araştırmadan farklıdır. Belki de itibarın diğer boyutları bu noktada etkili olmaktadır ya da kültürel değerler ilişkiyi etkilemektedir. İlişkinin söz olduğu diğer yollarla ilgili yorum yapmak için Şekil 3.'te görülen standartlaştırılmış değerlere bakılmıştır. 


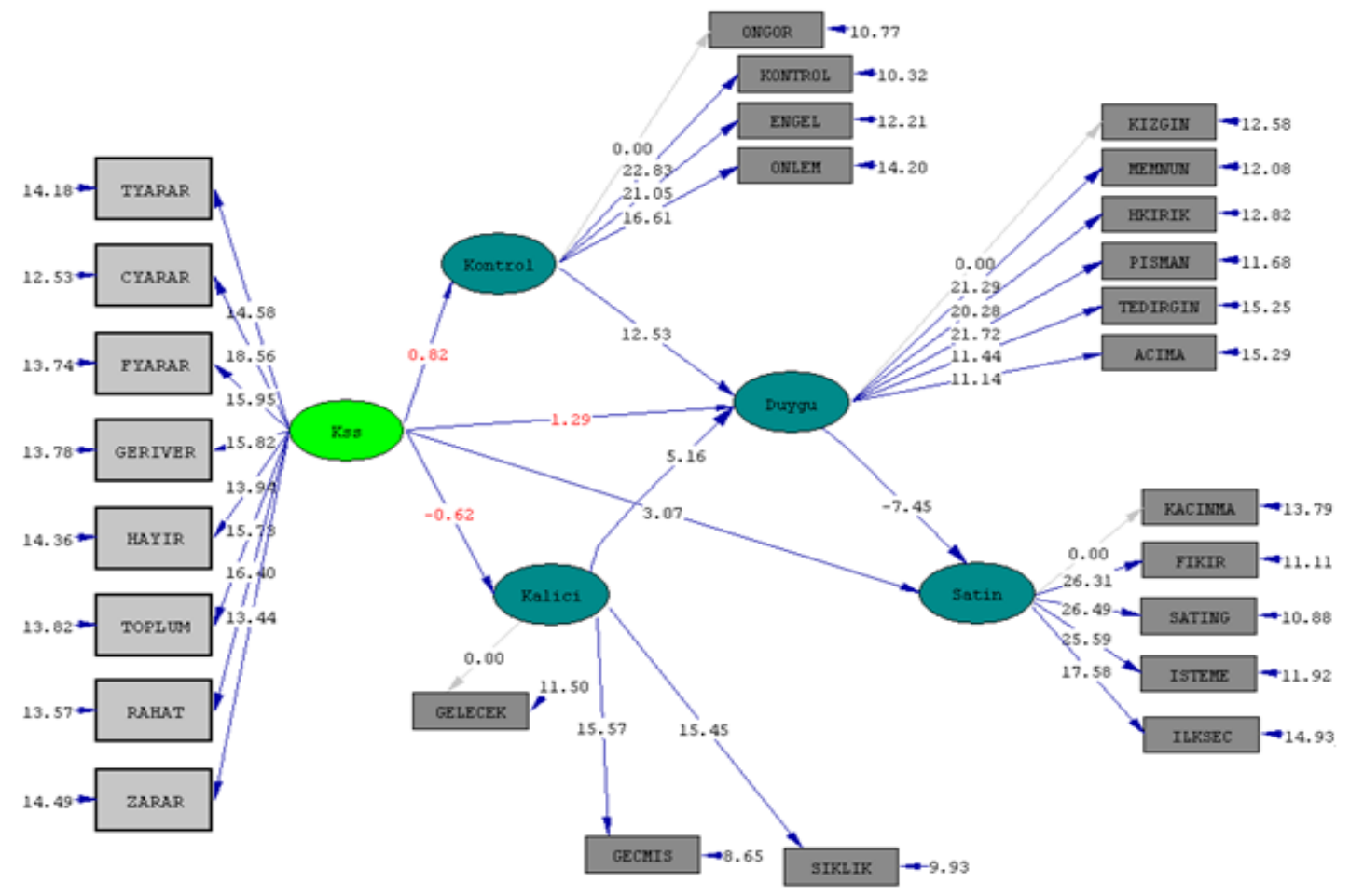

Chi-Square $=868.02, d f=292$, P-value $=0.00000$, RMSEA $=0.063$

Şekil 2: Sosyal Sorumlu İşletme İçin Yapısal Modelin T Değerleri

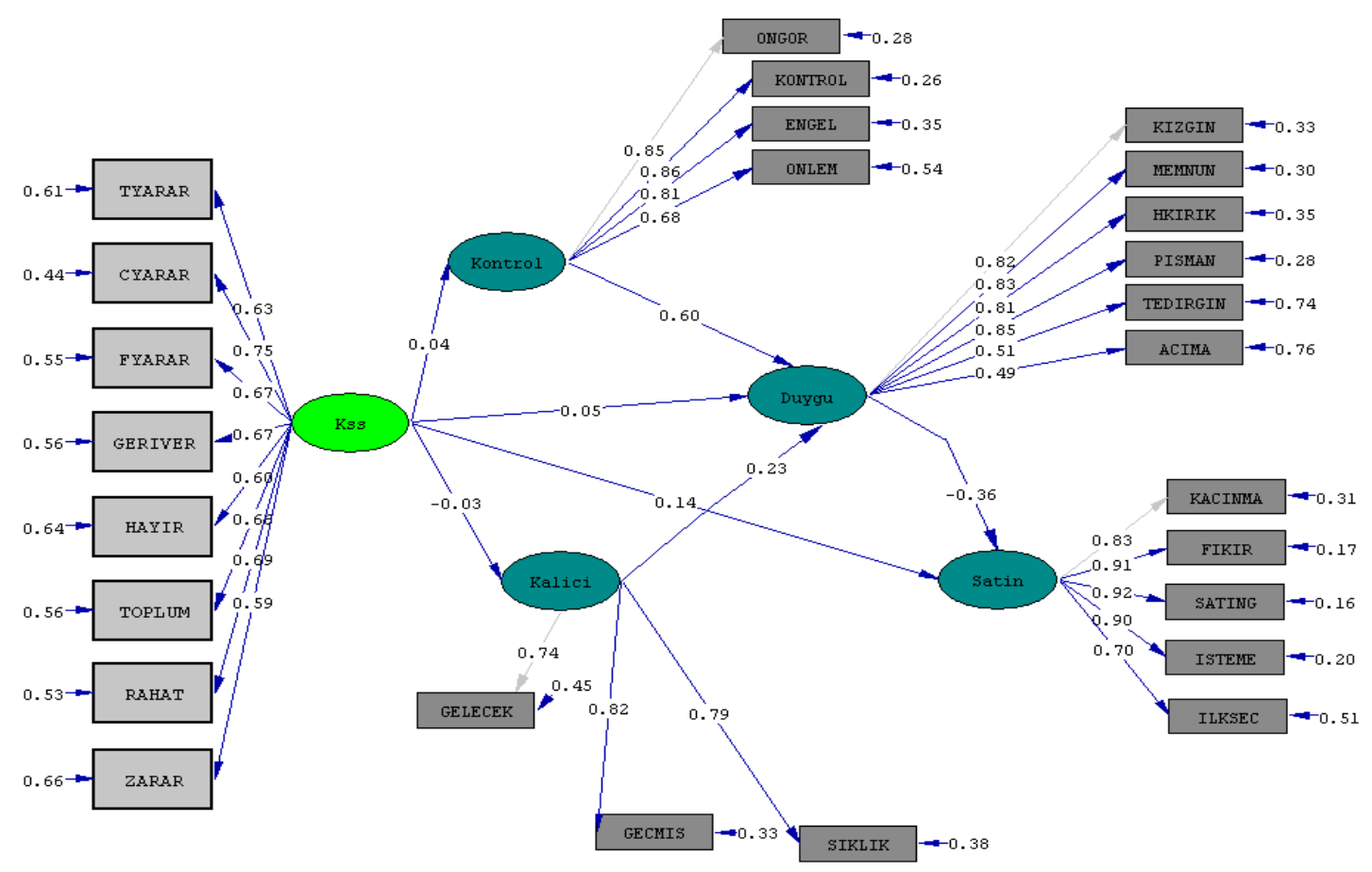

Chi-square=868.02, df=292, P-value=0.00000, RMSEA=0.063

Şekil 3: Sosyal Sorumlu İşletme İ̧̧in Yapısal Modelin Standartlaştırılmış Değerleri

Standartlaştırılmış değerlere göre, işletmenin sosyal sorumluluk durumunun müşterilerin tekrar satın alma niyetleri üzerinde doğrudan pozitif yönde etkisi vardır. $\mathrm{H}_{5}$ desteklenmişsir. İşletmenin sosyal sorumluluk düzeyi 
arttıkça tekrar satın alma niyeti de artmaktadır. Ancak bu etki düşük $(0,14)$ düzeydedir. Bunun nedeni ürün krizinin neden olduğu olumsuzluğun ilişki üzerindeki etkisi olabilir. İşletme her ne kadar sosyal sorumlu olsa da ürün krizinin yaşanması tüketicileri ürünü tekrar satın alma konusunda düşündürebilir. Atıf-kontrol boyutunun ürün krizi sonrasında hissedilen duygular üzerinde doğrudan pozitif yönde ve yüksek düzeyde $(0,60)$ bir etkisi vardır. $H_{1 a}$ desteklenmiştir. Atıf-kalıcılık boyutunun ürün krizi sonrasında hissedilen duygular üzerinde doğrudan pozitif yönde ve ortaya yakın düzeyde $(0,23)$ bir etkisi vardır. $H_{1 b}$ desteklenmiştir. Buna göre ürün krizinin işletme tarafından kontrol edilebilir olarak algılanması durumunda tüketicilerin duygularındaki olumsuzluk derecesi sorunun kalıcı olması durumuna göre daha yüksektir. Bu nedenle, işletme sosyal sorumlu ise ürün krizi yaşandığında duygulara odaklanarak aklayıcı kampanyalar yürütebilir. Ürün krizi sonrasında hissedilen duyguların müşterilerin tekrar satın alma niyetleri üzerinde doğrudan negatif yönde ve orta düzeyde $(-0,36)$ bir etkisi vardır. $\mathrm{H}_{2}$ desteklenmiştir. Bu bulguya göre duygulardaki olumsuzluk arttıkça tekrar satın alma niyeti azalmaktadır.

\subsubsection{Sosyal Sorumlu Olmayan İşletme İçin Yol Analizi}

Sosyal sorumlu olmayan işletme uyum indeksleri değerleri $\quad X^{2} / \mathrm{sd}=2,37 ; \quad \mathrm{CFI}=0,94 ; \quad \mathrm{RMSEA}=0,053$; $\mathrm{GFI}=0,90 ; A G F I=0,88^{\prime}$ dir. Model verilere oldukça iyi uyum sağlamaktadır.T değerlerine baktığımızda Kss ile Duygu değişkenleri arasındaki ilişkiyi gösteren değer dışındaki bütün değerler 0,05 anlamlılık düzeyinde 1,96 değerinden büyük ve istatistiksel olarak anlamlıdır. Buna göre işletmenin sosyal sorumluluk durumuyla duygular arasında bir ilişki olmadığını söyleyebiliriz. Böylece $\mathrm{H}_{4}$ reddedilmiştir. T değerleri Şekil 4.'te yer almaktadır.

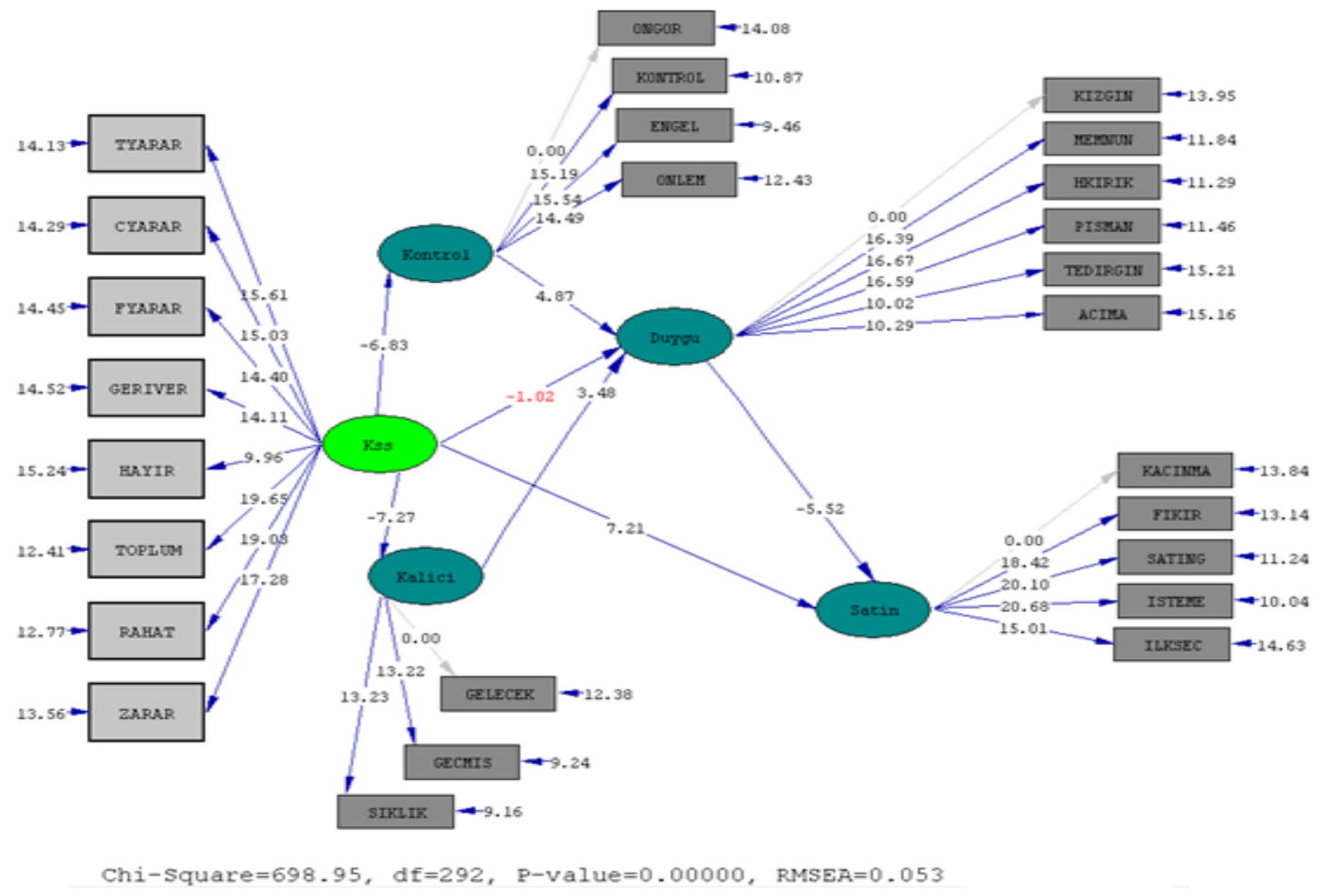

Şekil 4: Sosyal Sorumlu Olmayan Işletme İçin Yapısal Modelin T Değerleri 


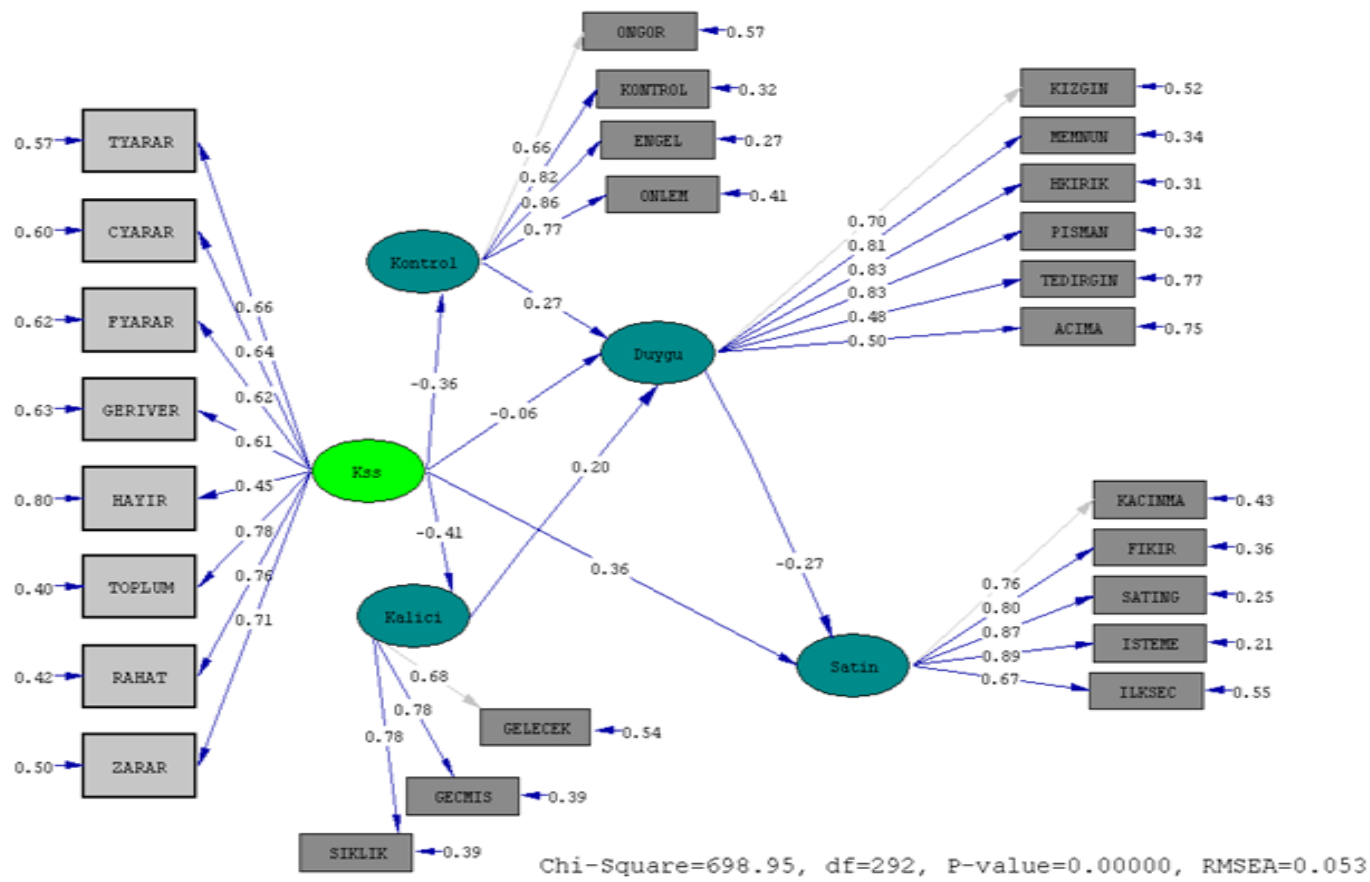

Şekil 5: Sosyal Sorumlu Olmayan İşletme İçin Yapısal Modelin Standartlaştırılmış Değerleri

Standartlaştırılmış değerlere göre işletmenin sosyal sorumluluk durumunun atıf-kontrol boyutu üzerinde doğrudan negatif yönlü ve orta düzeyde $(-0,36)$, atıfkalıcılık boyutu üzerinde doğrudan negatif yönde ve yükseğe yakın düzeyde $(-0,41)$, müşterilerin tekrar satın alma niyetleri üzerinde doğrudan pozitif yönde ve orta düzeyde $(0,36)$ etkisi vardır. $\mathrm{H}_{3 \mathrm{a}}$ ve $\mathrm{H}_{3 \mathrm{~b}}$ desteklenmiştir. İşletme sosyal sorumlu olmadığı için tüketiciler sorunun tekrar yaşanacağını ve yaşanan sorunun aslında işletme tarafından kontrol edilebilir olduğunu düşünmektedirler. Bu olumlu bir düşünce değildir. Özellikle sorunun kalıcı olarak düşünülmesi tüketicileri satın almaktan vazgeçirebileceği için uzun vadede işletmenin satışlarını olumsuz yönde etkileyecektir. Buna ek olarak olumsuz sosyal sorumluluğun ürün krizinin kalıcı olarak algılanması üzerindeki etisi kontrol edilebilirliğe göre daha yüksektir. İşletmenin sosyal sorumluluk durumu aynı zamanda müşterilerin tekrar satın alma niyetlerini doğrudan, pozitif yönde ve orta düzeyde $(0,36)$ etkilemektedir. $H_{5}$ desteklenmiştir. Işletmenin sosyal sorumluluk derecesi azaldıkça tekrar satın alma niyetleri de azalmaktadır. Sosyal sorumluluk durumundan etkilenen atıflar açısından sonuçlara baktığımızda, duygular üzerinde kontrol edilebilirlik ve kalıcılık boyutlarının her ikisinin de doğrudan pozitif yönde ve orta düzeyde etkisi olduğu bulunmuş, $\mathrm{H}_{1 a}$ ve $\mathrm{H}_{1 \mathrm{~b}}$ desteklenmiştir. Kontrol edilebilirlik boyutunun etkisi $(0,27)$ kalıcılığa göre $(0,20)$ biraz daha yüksektir. $\mathrm{Bu}$ bulguya göre sorun kontrol edilebilir ve kalıcı olarak algılandıkça duygulardaki olumsuzluklar da artmaktadır. Bu bulgu bize aynı zamanda işletme sosyal sorumlu değilken, sosyal sorumluluk durumunun duygular üzerinde atıflar aracılığıyla etkisi olduğunu göstermektedir. Bu da aslında olumsuz durumlarda nedensel çıkarımlar yapmanın önemini ortaya koymaktadır. Duyguların tekrar satın alma niyetine $(-0,27)$ etkisi olduğu da ortaya çıkmış, $\mathrm{H}_{2}$ desteklenmiştir. Ürün krizi sonrasında hissedilen olumsuz duygular arttıkça müşterilerin tekrar satın alma niyetleri de azalmaktadır.

Sonuç olarak yapılan analizler sonrasında nihai olarak Şekil 6. ve Şekil 7.'deki modeller elde edilmiştir. 


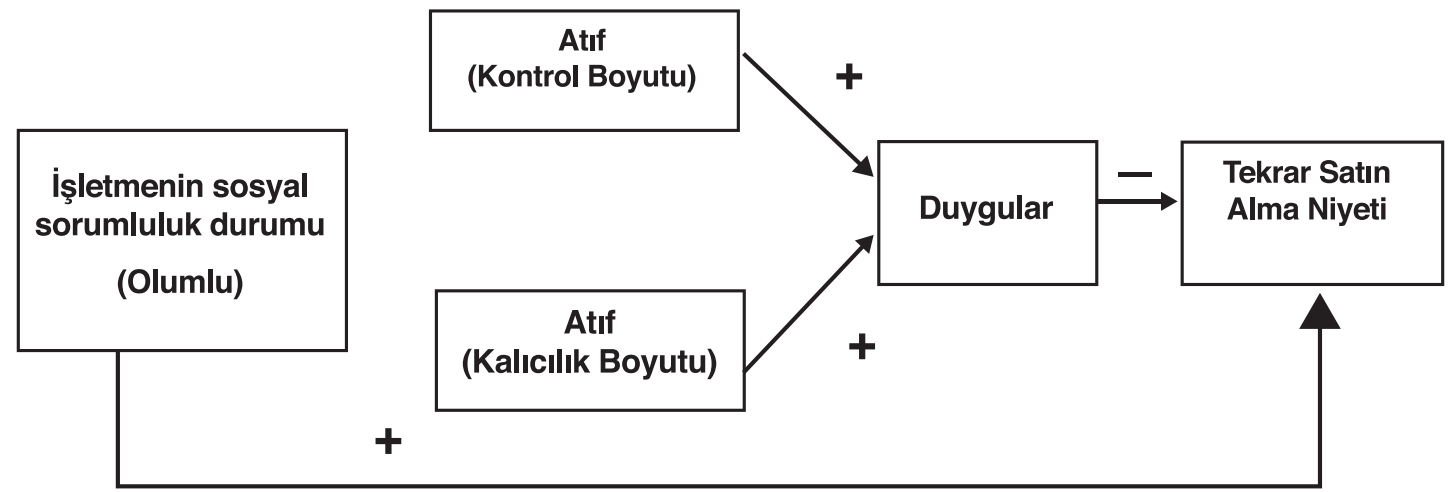

Şekil 6: İşletmenin Sosyal Sorumlu Olduğu Durum İçin Model

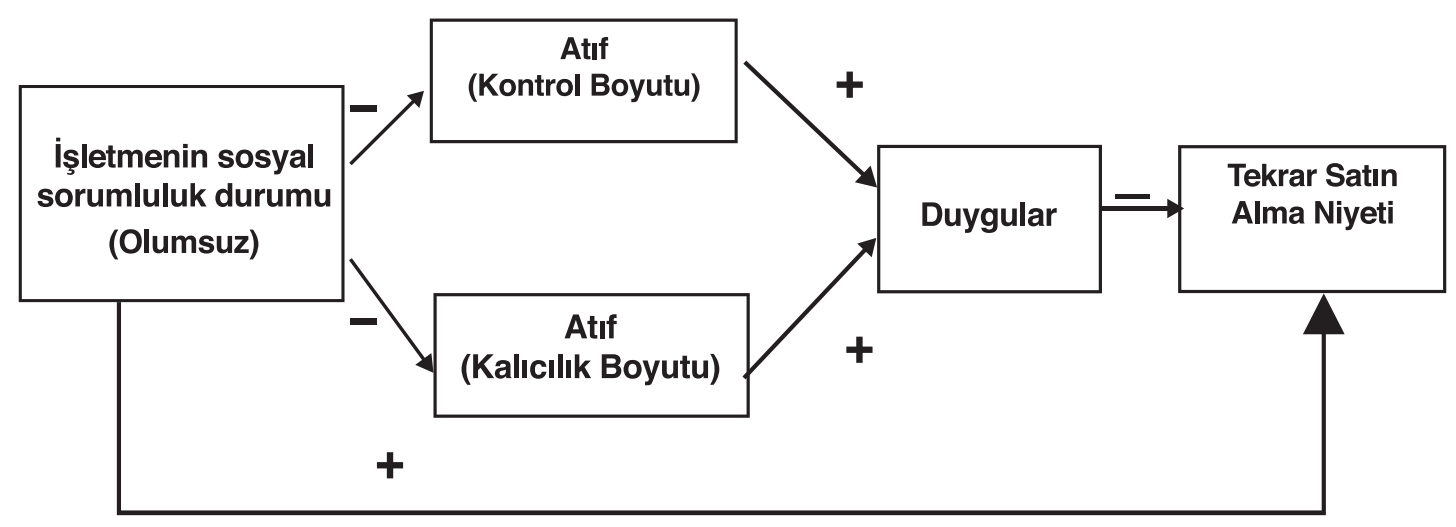

Şekil 7: Iş̧letmenin Sosyal Sorumlu Olmadığı Durum İ̧̧in Model

\section{SONUÇ}

Bu çalışmada ürüne ilişkin bir kriz yaşandığında tüketicilerin atfetme sürecinin nasıl gerçekleştiği ve işletmenin sosyal sorumluluk durumunun tüketici atfetme süreci elemanlarını nasıl etkilediği araştıııımış, bir araştırma modeli önerisinde bulunulmuştur. Yapılan analizler sonrasında önerilen modelin büyük ölçüde beklendiği gibi çıktığı gözlemlenmiştir. Atfetme süreci atıf-duygu-davranış niyeti şeklinde meydana gelmektedir. Satın aldığı bir üründe sorun yaşama intimali olan bir tüketici aynı işletmeden tekrar satın alım yapma yönünde nihai kararını verirken ilk olarak bilişsel bir şekilde sorunun nedenini düşünmekte daha sonra duygusal ve davranışsal tepkiler vermektedir. Sosyal sorumluluk durumunun etkisi için sonuçlara baktığımızda birtakım benzerliklerin ve farklılıkların olduğu tespit edilmiştir. İlk olarak, ürün krizi yaşandığında olumlu bir sosyal sorumluluk imajının tekrar satın alma niyetine etkisi dışında pek de olmadığı söylenebilir. Bu önemli bir bulgudur. Tüketiciler zihinlerinde bir markayı nasıl konumlandırdırlarsa düşünce ve duygular o şekilde devam ediyor demektir. Ancak işletme sosyal sorumlu değilse durum tam tersi bir hal almaktadır. Sosyal sorumlu olmamak ters tepmekte ve olumsuz bir durum oluşmaktadır. Sosyal sorumluluk durumu işletme sosyal sorumluyken bilişsel tepki olan atıfları etkilememekte, işletme sosyal sorumlu değilken atıfları negatif yönde etkilemektedir. Işletme sosyal sorumlu değilse tüketiciler, sorunun işletme tarafından kontrol edilebilir ve yüksek ölçüde kalıcı olduğunu düşünmektedir. Bu bulgu olumlu bir sosyal sorumluluk imajının tüketiclerin atıflarını etilemezken, olumsuz bir imajın atıflar üzerinde etkili olduğu sonucuna götürmektedir. Diğer bir deyişle olumsuz bir imaj olumsuz çıkarımlar yapılmasında etkili olmaktadır. Sosyal sorumluluk durumunun doğrudan etkilediği diğer bir değişken davranışsal tepki olan tekrar satın alma niyetidir. İşletmenin sosyal sorumlu olduğu ve olmadığı her iki durum için de bu etki vardır. Ancak işletme sosyal sorumlu değilken etki daha yüksektir. Buna göre olumsuz imaj, tekrar satın alma niyetindeki azalmada daha etkili demektir. İşletmenin sosyal sorumlu olmadığı durumda sosyal sorumluluk durumu, duyguları atıflar aracılığıyla etkilemektedir. Işletme sosyal sorumlu olduğunda ise sosyal sorumluluk durumunun duygular üzerinde doğrudan ya da dolaylı 
bir etkisi yoktur. Atıfların etkisi incelendiğinde her iki durum için kalıcılık boyutunun duygular üzerinde benzer düzeyde etkisi varken işletme sosyal sorumlu olduğunda kontrol boyutunun duygular üzerindeki etkisi daha yüksektir. Bunu, işletmenin sosyal sorumlu olması durumunda, müşterilerin duygular açısından daha hassas olabileceği şekilde yorumlayabiliriz. Isşletme sosyal sorumlu olduğunda da olmadığında da müşterilerin olumsuz duygularının, tekrar satın alma isteği üzerinde negatif yönlü etkisi vardır. İşletme sosyal sorumlu olduğunda bu etkinin düzeyi biraz daha yükselmektedir. Bu durum kontrol edilebilir bir krizin olumsuz duygular üzerindeki etkisinin bir yansıması olabilir. Belki de sosyal sorumlu olduğu zaman işletmeden böyle bir hata beklemeyen müşteriler duygularını daha yoğun yaşamakta ve bu olumsuz hisler etkisini tekrar satın alma konusunda daha isteksiz davranma şeklinde gösterebilmektedir.

Tüm bu sonuçlardan yola çıkarak işletme yöneticilerine birtakım önerilerde bulunulabilir. İlk olarak işletmeler olumsuz bir sosyal sorumluluk imajına sahip olmamaya dikkat etmelidirler. Olumsuz bir sosyal sorumluluk imajı olumsuz düşüncelere ve davranışsal niyetlere neden olmaktadır. Olayın nedenine ilişkin açıklamalarda ve duygularda her ne kadar etkisi olmasa da işletmelerin sosyal sorumlu olmalarının, ürüne ilişkin kriz yaşamaları durumunda, müşterilerin tekrar satın alma niyetindeki olumsuz tepkiyi azaltması nedeniyle bu tür uygulamalar işletmelerin stratejik planlarında yer almalıdır. Bu faaliyetlerin, krizden kurtulmak amacıyla yapılıyor gibi bir izlenim yaratılmaması adına kriz öncesi dönemde yürütülmesinde yarar vardır. Kriz döneminde sosyal sorumlu olan bir işletme müşterilerin duygularını olumluya çevirerek ya da olumsuzluk derecesini azaltarak krizin tekrar satın alma niyetindeki üzerindeki olumsuz etkisini azaltabilir. Kriz durumunda işletmeler, müşterilerin satın alma niyetindeki olumsuzluğu azaltmak için kurumsal sosyal sorumluluk uygulamaları dışında da birşeyler yapabilir. Örneğin kurumun müşteriler nezdinde daha önce sahip olduğu itibarı hatırlatacak reklamlar yapılabilir, işletmenin sosyal sorumlu olduğu durumlarda daha önce yapılan projeler iletişim çalışmalarıyla hatırlatılabilir. Basın toplantıları düzenlenerek krizin nedenlerinin ve işletmenin kriz sürecinde uygulayacağı politikaların kısa açıklamaları yapılabilir. İşletme gerçekten sosyal sorumluysa bu tür açıklamalar toplum tarafından beklenecektir. Yararlanılabilecek diğer bir araç günümüzde popülerliği ve kullanımı giderek artan sosyal medyadır. İşletmelerin sosyal medya hesapları açarak kendileri hakkında yapılan yorumları takip etmeleri ve buna göre girişimlerde bulunmaları son derece faydalı olacaktır.

Araştırmanın kısıtı araştırmanın belirli bir ürün grubu üzerinde yapılmasıdır. Bu nedenle sonuçlar tüm sektörler için genellenememektedir. Yapılacak gelecek çalışmalarda farklı bir ürün üzerinden ya da hizmet sektörü düşünülerek senaryolar yazılabilir. Gerçek bir kriz durumuna ilişkin araştırma yapılabilir. Literatürde etkisi olabileceği düşünülen, güven (Vlachos vd.,2009), sosyal sorumluluk kampanyasının konusu (Sen ve Bhattacharya, 2001) ve sadakat (Delgado Ballaster ve Munuera-Aleman, 2005) değişkenleri eklenerek model tekrar test edilebilir. 


\section{KAYNAKLAR}

Akdağ, M. ve Arklan, Ü. (2011) "Kriz Yönetimi ve Kurumsal Sosyal Sorumluluk: Kurumsal Sosyal Sorumluluğun Kriz Yönetimi Sürecine Etkisi/Katkısı", e-Journal of New World Sciences Academy 4(6): 768784.

Akdoğan, F. Küskü ve Bay, E. (2012) İsteğe Bağlı Kurumsal Sosyal Sorumluluk Faaliyetleri: Görünürde Hayırseverlik, Amme Idaresi Dergisi 45(1): 51-75.

Aktan, C. C. ve Börü, D. (2006) Kurumsal Sosyal Sorumluluk. Kurumsal Kültür Editör Coşkun Can Aktan, Ankara: SPK Yayını.

Assiouras, I.; Ozgen, Ö. ve Skourtis, G. (2013) “The Impact of Corporate Social Responsibility in Food Industry in Product-Harm Crises", British Food Journal 1(115): 108-123

Bayraktar, T. ve Güvenç, D. (2014) Meslek Yüksekokulu Öğrencilerinin Kurumsal Sosyal Sorumluluk Algısını Belirleme Üzerine Bir Araştırma: Kandıra Meslek Yüksekokulu Örneği, Çalışma İlişkileri Dergisi 5(2): 30-23.

Bemmels, B. (1991) "Attribution Theory and Discipline Arbitration", Industrial and Labor Relations Review, 44(3): 548-562.

Bigne-Alcaniz, E.; Curras-Perez, R. ve Sanchez-Garcia, I. (2009) "Brand Credibility in Cause-Related Marketing: the Moderating Role of Consumer Values", Journal of Product and Brand Management 18(6): 437-447.

Bitner, M.J. (1990) “Evaluating Service Encounters: The Effects of Physical Surroundings and Employee Responses", Journal of Marketing Research, 54(2):69-82.

Brown, T.J. ve Dacin, P.A. (1997) "The Company and the Product: Corporate Associations and Consumer Product Responses", Journal of Marketing 61(1): 68-84.

Casado-Díaz, A. B. ve Más-Ruíz, F. J. (2002) "The Consumer's Reaction to Delays in Service", International Journal of Service Industry Management 13(2): 118140.

Coombs, W.T. ve Holladay, S.J. (2002). Helping Crisis Managers Protect Reputational Assets: Initial Tests of The Situational Crisis Communication Theory, Management Communication Quarterly 16: 165-186.

Coombs, W. T. (2007) “Protecting Organization Reputations During a Crisis: The Development and Application of Situational Crisis Communication Theory", Corporate Reputation Review 10(3): 163-176.
Curren, M. T. ve Folkes, V. S. (1987) "Attributional Influences on Consumer's Desire to Communicate about Products", Psychology and Marketing 4: 31-45.

Çokluk, Ö.; Şekercioğlu, G. ve Büyüköztürk, Ş. (2012) Sosyal Bilimler için Çok Değişkenli İstatistik SPSS ve LISREL Uygulamaları. 2 Baskı, Ankara:PEGEM Akademi.

Darling, J. R. (1994) “Crisis Management in International Business: Keys to Effective Decision Making", Leadership \& Organization Development Journal 15(8): 3-8.

Davidson, W. N. ve Worrell, D. L. (1992) “Research Notes and Communications: The Effect of Product Recall Announcements on Shareholder Wealth", Strategic Management Journal 3: 467-473.

Davis, K. (1960). Can Business Afford to Ignore Social Responsibilities?, California Management Review. 2(3): 70-76.

Dawar, N. ve Pillutla, M. M. (2000) "Impact of Product-Harm Crises on Brand Equity: The Moderating Role of Consumer Expectations", Journal of Marketing Research 37(2): 215-226.

Delgado Ballaster, E. ve Munuera-Aleman, J. (2005) "Does Brand Trust Matter to Brand Equity?", Journal of Product and Brand Management, 14(3):187-196.

Dinçer, M.A. ve Özdemir, Y. (2013) Kurumsal Sosyal Sorumluluk Uygulamaları ve Eşbiçimlilik: On Büyük Türk Holdingi Üzerine Vaka Çalışması, Afyon Kocatepe Üniversitesi i.I.B.F. Dergisi, 15(2): 31-66.

Donoghue, S. ve de Klerk, H. M. (2006)“Dissatisfied Consumers' Complaint Behaviour Concerning Product Failure of Major Electrical Household Appliances - a Conceptual Framework", Journal of Family Ecology and Consumer Sciences 34: 41-55.

Folkes, V. S. (1984) "Consumer Reactions to Product Failure: An Attributional Approach", Journal of Consumer Research 10(4): 398-409.

Folkes, V. S. ve Kotsos, B. (1986) "Buyers' and Sellers' Explanations for Product Failure: Who Done It?", Journal of Marketing April: 74-80.

Folkes, V.S., Koletsky, S. ve Graham, J. (1987) “A Field Study of Causal Inferences and Consumer Reaction: The View From The Airport", Journal of Consumer Research, 13(4):534-539.

Goss, R.J., Silvera, D.H., Laufer, D. ve Gillespie, K. (2011) Uh-Oh, This Might Hurt Our Bottom Line: Consumer and Company Reactions to Product Harm Crises, 
Working Paper. Advances in Consumer Research 39:83-832.

Hess, R. L.; Ganesan, S. ve Klein, N. M. (2003) "Service Failure and Recovery: the Impact of Relationship Factors on Customer Satisfaction", Journal of the Academy of Marketing Science 31(2): 127-145.

Hsu, M.Y. ve Cheng, J.M .(2018) "fMRI Neuromarketing and Consumer Learning Theory: Word-of-Mouth Effectiveness After Product Harm Crisis", European Journal of Marketing, (52)1/2:199-223.

Kağıtçıbaşı, Ç. ve Cemalcılar, Z. (2014). Dünden Bugüne İnsan ve İnsanlar: Sosyal Psikolojiye Giriş, 16. Basım, İstanbul: Evrim Yayınları.

Kahraman, A. (2016). Kurumsal Sosyal Sorumluluk Faaliyetlerinin Ürüne İlişkin Kriz Dönemlerinde Tüketicilerin Satın Almaya Yönelik Davranışlarına Etkisi: Atfetme Teorisine Yönelik Bir Uygulama, Yayımlanmamış Doktora Tezi. Manisa Celal Bayar Üniversitesi Sosyal Bilimler Enstitüsü.

Kanıbir, H., Nart, S. ve Saydan, R. (2011) Tüketici Davranışında Kurumsal Sosyal Sorumluluk Faaliyetleri Belirleyici mi? KSS- Algılama- Bağlılık Zincirinin İşlerliğine Dair Bir Sorgulama, Tüketici ve Tüketim Araştırmaları Dergisi 3(2): 1-39

Kaya, H. (2008) Demografik Özelliklerin Kurumsal Sosyal Sorumluluk Algılaması Üzerindeki Rolü: Bandırma Yerelinde Bir Araştırma, Balıkesir Üniversitesi Sosyal Bilimler Enstitüsü Dergisi. 11(20): 96-110.

Kızgın, Y. ve Dalgın, T. (2012) "Atfetme Teorisi: Öğrencilerin Başarı ve Başarısızlıklarını Değerlendirmedeki Atfetme Farklılıkları", ZKÜ Sosyal Bilimler Dergisi 8(15): 61-63.

Klein, J. ve Dawar, N. (2004) "Corporate Social Responsibility and Consumers' Attributions and Brand Evaluations in a Product-Harm Crisis", International Journal of Research in Marketing 21(3): 203-217.

Kotler, P. ve Lee, N., (2006) Kurumsal Sosyal Sorumluluk. Çeviren Sibel Kaçamak, İstanbul: Mediacat Yayınları.

Laczniak, R.N.; De Carlo, T. E. ve Ramaswami, S. N. (2001), 'Consumers' Responses to Negative Wordof-Mouth Communication: An Attribution Theory Perspective", Journal of Consumer Psychology 11(1): 57-73.

Lalonde, C. (2007) Crisis Management and Organizational Development: Towards the Conception of a Learning Model in Crisis Management, Proceedings of OLKC 2007- Learning Fusion:507-517.

Lei; J., Dawar, N. and Gürhan-Canlı, Z. (2012) "BaseRate Information in Consumer Attributions of
Product-Harm Crise, Journal of Marketing Research, 49 (June): 336-348.

Menon, S. ve Kahn, B. (2003) “Corporate Sponsorships of Philanthropic Activities: When Do They Impact Perception of Sponsor Brand?", Journal of Consumer Psychology 13(3):316-327

Mullan, J.G. (2004) Reporting Safety Problems: U.S. Perspective. http://www.icphso.org/oldfiles/international/2004Euro/2004/London1.pdf. , (07.02.2014).

Nakra, P. (2000) "Corporate Reputation Management: CRM with a Strategic Twist?", Public Relations Quarterly: 35-42.

Nikbin, D.; Ismail, I.; Marimuthu, M. and Abu-Jarad, I. (2011) "The Impact of Firm Reputation on Customers' Responses to Service Failure: The Role of Failure Attributions", Business Strategy Series 12(1):19-29

Ofluoğlu,G. ve Mısırlı, K. (2001). “Isşletme ve Kriz Yönetimi". Kamu-Iş Dergisi 6(2): 3-30.

Ortiz, J.; Chiu, T.; Wen-Hai, C. ve Hsu, C. (2017) “Perceived Justice, Emotions, and Behavioral Intentions in The Taiwanese Food and Beverage Industry", International Journal of Conflict Management 28(4):437-463.

Örnek, A. Ş. (2007). "Kriz Yönetimi Stratejileri ve Türkiye Bilişim Sektörü Örneği", Yönetim Bilimleri Dergisi-Journal of Administrative Sciences 1(5): 114-129.

Öksüz, B. (2014) Halkla İlişkiler ve Kurumsal Sosyal Sorumluluk İlişkisi: Kurumsal Mı Sosyal Mi?, Selçuk Üniversitesi Illetişim Dergisi 8(3): 55-75.

Özdemir, H (2009) Kurumsal Sosyal Sorumluluğun Marka İmajına Etkisi, İstanbul Ticaret Üniversitesi Sosyal Bilimler Dergisi 8(15): 57-72.

Özgen, E. (2007). “Kurumsal Sosyal Sorumluluk Kavramı ve Çalışan Memnuniyetine Etkisi". D.Ü. Ziya Gökalp Eğitim Fakültesi Dergisi 8:1-6.

Pira, A. ve Sohodol, Ç. (2004). Kriz Yönetimi: Halkla İlişkiler Açısından Bir Değerlendirme. İstanbul: İletişim Yayıncılık.

Pomering, A. ve Johnson, L.W. (2009) Constructing a Corporate Social Responsibility Reputation Using Corporate Image Advertising, Australasian Marketing Journal 17:106-114.

Poon, P.S.; Hui, M.K. ve Au, K. (2004) "Attributions on Dissatisfying Service Encounters: A Cross-cultural Comparison between Canadian and PRC Consumers", European Journal of Marketing 38(11-12): 1527-1540.

Sen, S. ve Bhattacharya, C.B. (2001) “Does Doing Good Always Lead to Doing Better? Consumer Reactions 
to Corporate Social Responsibility", Journal of Marketing Research, May, 38(20):225-243

Sert, N. Yılmaz (2012) Türkiye'de Özel Sektörün Kurumsal Sosyal Sorumluk Anlayışına Illişkin Yarar Algısı: Kurumsal Sosyal Sorumluluk Faaliyetlerinin Duyurulmasında Web Sitelerinin Kullanılması, Online Academic Journal of Information Technology 9(3): 31-50.

Smith, A.K. ve Bolton, R.N. (2002) "The Effect of Customers'Emotional Responses to Service Failures on Their Recovery Effort Evaluations and Satisfaction Judgments", Journal of the Academy of Marketing Science 30(1): 5-23.

Siomkos, G.J. ve Kurzbard, G. (1994). "The Hidden Crisis in Product-Harm Crisis Management", European Journal of Marketing 28(2): 30-41.

Siomkos, G. J. (1999) "On Achieving Exoneration After a Product Safety Industrial Crisis", Journal of Business and Industrial Marketing 14:17-29.

Top, S. ve Öner, A. (2008) İşletme Perspektifinden Sosyal Sorumluluk Teorisinin İncelenmesi, ZKÜ Sosyal Bilimler Dergisi 4(7): 97-110.

Ural, E. Güzelcik (2012) Kurumsal İtibarı Ölçme Yöntemi Olarak Türkiye İtibar Endeksi ve Endeks Sonuçlarından Hareketle Türkiye'de Elektronik Sektörünün İtibarı Üzerine Bir Değerlendirme, AJIT-e: Online Academic Journal of Information Technology 3(7): 7-20.

Uslu, A., Gambarov, V. ve Başçı, A., (2008) Türkiye'de Tüketicilerin Sosyal Sorumluluk Kampanyalarına ve Sosyal Açıdan Sorumlu Şirketlere Karşı Tutumu. ODTÜ Muhan Sosyal İşletmecilik Konferansı Kitabı. Düzenleyen Orta Doğu Teknik Üniversitesi. Ankara. 3-6 Eylül 2008.

Vassilikopoulou, A.; Siomkos, G. J.; Chatzipanagiotou, K. ve Pantouvakis, A. (2009) "Product-Harm Crisis Management: Time Heals All Wounds?". Journal of Retailing and Consumer Services 16(3): 174-180.

Vassilikopoulou, A.; Chatzipanagiotou, K.; Siomkos, G. J. ve Triantafillidou, A. (2011) “The Role of Consumer
Ethical Beliefs in Product-Harm Crises", Journal of Consumer Behaviour 10: 279-289

Vlachos, P. A.; Tsamakos, A.; Vrechopoulos, A, P. ve Avramidis, P. K. (2009) "Corporate Social Responsibility: Attributions, Loyalty and the Mediating Role of Trust", Journal of the Academy of Marketing Science 37(2): 170-180

Wang, S. ve Huff, L. C. (2007) "Explaining Buyers' Responses to Sellers' Violation of Trust" European Journal of Marketing 41(9-10): 1033-1052.

Weiner, B. (2000) "Attributional Thought about Consumer Behavior", Journal of Consumer Research 27(3): 382-387.

Weiner, B. (1985) "An Attributional Theory of Achievement Motivation and Emotion". Psychological Review 92(4): 548-573.

Weiner, B. (1980) "A Cognitive (Attribution)-Emotion-Action Model of Motivated Behavior: An Analysis of Judgments of Help-Giving", Journal of Personality and Social Psychology 39(2): 186-200.

Weiner, B. (1983) "Some Methodological Pitfalls in Attributional Research", Journal of Educational Psychology 75(4): 530-543.

Wetzer, I.M., Zeelenberg, M. ve Pieters, R. (2007) Never Eeat in That Restaurant, I Did!: Exploring Why People Engage in Negative Word-of-Mouth Communication, Psychology \& Marketing, 24(8): 661-680.

Yazıcıoğlu, Y. ve Erdoğan, S. (2007). SPSS Uygulamalı Bilimsel Araştırma Yöntemleri, 2. Baskı, Ankara:Detay Yayıncilık.

Yoon, Y.; Gurhan-Canli, Z. ve Schwarz, N. (2006). “The Effect of Corporate Social Responsibility (CSR) Activities on Companies with Bad Reputations", Journal of Consumer Psychology 16(4): 377-390.

Yönet, E. (2005) Kurumsal Sosyal Sorumluluk Anlayışında Son Dönemeç: Stratejik Sorumluluk, Balıkesir Üniversitesi Sosyal Bilimler Dergisi. 13(8): 239-265.

Zeithaml, V. A.; Berry, L. L. ve Parasuraman, A. (1996) "The Behavioral Consequences of Service Equality", Journal of Marketing 60: 31-46. 